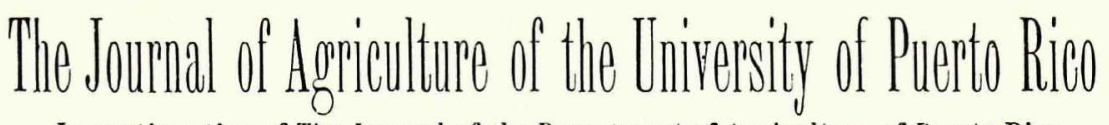

In continuation of The Journal of the Department of Agriculture of Puerto Rico Published by The Agricultural Experiment Station, Rio Piedras, P. R.

Published Qnarterly: Jannary, A pril, July and 0ctober of each year.

MeLVILLE T. CoOK, EDITor

\begin{tabular}{lll}
\hline VoL. XXII & APRIL 1938 & No. 2 \\
\hline
\end{tabular}

\title{
THE NUTRITIVE VALUES OF SOME FORAGE CROPS OF PUERTO RICO ${ }^{1,2,3}$
}

\section{Grasses}

By J. H. Axtmayer, C. F. Asenjo and D. H. Cook, of the Department of Chemistry, School of Tropical Medicine, San Juan, P. R.

\section{INTRODUCTION}

The importance of the knowledge of the feeding value of forage crops in relation to the modern livestock and dairy industries is recognized.

Metabolic experiments carried out with lambs have proved to be an acceptable and practical method of determining nutritional indexes of feeds, such as the biological value, coefficient of apparent digestibility, etc., these serving to give the relative nutritive values of different forage crops when fed to ruminants.

Since no work of this kind has been undertaken before in Puerto Rico, we have had up to the present time no exact knowledge concerning the nutritive values of the different pastures used in our dairy and livestock industry.

The data presented here has been collected from experiments carried out during the years 1936 and 1937 . We have tried to obtain information (similar to that collected in studies on forage crops in the United States) concerning the nutritive values of those pastures most commonly used on our Island, but in no way should this initial investigation be taken as a final dictum on the matter. In addition to the work which has been done to determine the nutritional indexes of the different grasses studied, we have also tried to obtain information regarding the influence such factors as the stage of maturity at the time of cutting, the cutting and the kind of fertilizer used, may have on the nutritive values of these grasses.

\footnotetext{
${ }^{1}$ Cooperative project between the Agricultural Experiment Station of the University of Puerto Rico and the School of Tropical Medicine.

2 Field work was conducted by the Experiment Station at Río Piedras.

${ }^{3}$ Study made possible from grant-in-aid of the Bankhead Jones Act of U. S. A. Congress 1936.
} 
These factors are of enough importance to be the subject of a special investigation. Therefore, justification for presenting the present study lies in the hope that the data given here shall serve to indicate the problems to be solved in a systematic study of the nutritive indexes of the forage crops of our Island.

\section{ReviEw of the LtTerature}

Although literature on the present subject is non-existent in Puerto Rico, it is so extensive in the States that it seems unnecessary for us to present more than a review of those studies from which we have taken our method. Sotola points out that the most accurate method of evaluating proteins at the present time appears to be that employed by Thomas and later modified by Mitchell (1). Mitchell performed a rigorous and extensive investigation of his method and came to the conclusion that it possessed a high degree of accuracy. It will be interesting to note that Mitchell used white rats as experimental animals. The method followed by Sotola (2) in his investigation on the biological value of the forage crops of the United States is similar to that recommended by Mitchell, being modified only in that Sotola used sheep instead of rats. The advisability of using sheep is clear, as results obtained in nutritive experiments with these animals have been shown to apply to cattle (3), and they are easier to work with.

The methods we followed in the determination of apparent coefficients of digestibility were the ones used by Sotola (4).

\section{Material and Methods}

The animals used in our experiment were native sheep whose ages ranged from six to eighteen months when purchased. We scarched the Island in the hope of finding a pure breed of sheep, but could not find a single farm where the breeding or care of sheep were carried out under controlled conditions. The animals had been allowed to roam about the farms and could not be used during the first two or three weeks after they were brought to the laboratory because they were practically unmanageable.

The grasses studied were grown at the Experiment Station Farm of the University of Puerto Rico at Río Piedras. A field of approximately 2 acres was divided into seventy-two $1 / 40$ acre plots, each treatment of the soil being replicated twelve times. One half of the replication was fertilized with a mixture of 400 pounds of 
ammonium sulphate and 200 pounds of double superphosphate per acre, and the other half was fertilized with 400 pounds of ammonium sulphate alone per acre.

The stages of maturation at which these grasses were cut were just before or during the flowering periods.

The cutting was done early in the morning, the grasses being chopped into pieces ranging from 2 to 4 inches in length, put into jute bags and sent to us by truck, arriving usually at about 8 or 9 $o$ 'clock in the morning.

The detailed field conditions under which the grasses were grown are given in table $\mathrm{A}$.

\section{EXPERTMENTAL}

Metabolism cages, $3 \frac{1}{2}$ feet long, 2 feet wide, and 3 feet high, similar to those used by Sotola (4) were constructed at the School shop. Each cage was provided with a double bottom for the collection of the urine and feces separately.

The animals, before beginning an experimental period, were kept during a preliminary period of 10 days on the ration to be tested. At the termination of this preliminary period, the animals were placed in the metabolism cages and the collection of the data for the experiment was begun. Each experiment lasted ten days.

The following data were collected during these ten-day experimental periods: 1. Initial and final weights of the animals at the start and the end of the experimental periods. 2. Weights of the feed consumed per day. 3. Weights of the feed refused per day. 4. Weights of the feces eliminated per day. 5. Volumes of the water consumed per day. 6. Volumes of the urine eliminated per day.

These data were collected practically at the same time every day, from 9 to $10 \mathrm{a} . \mathrm{m}$., and aliquot samples of the feeds given, the refuse left, and the feces and urine eliminated, were taken for analysis.

All the solid samples collected were dried in an air oven at $100^{\circ} \mathrm{C}$. The composite aliquot samples of the feces and urine were kept in the ice box. Xylol was added to the urine as preservative. The samples of the grasses were kept in paper bags after having been dried. All the solid samples were ground in a Willy mill at the end of each experimental period; the powder obtained was mixed, and large enough portions of it were put into amber bottles provided with tight stoppers to be preserved for analysis. All the analyses reported in this study have been performed according to the methods of the Association of Official Agricultural Chemists. In the case of the nitrogen determinations, we used a solution consisting of ten 


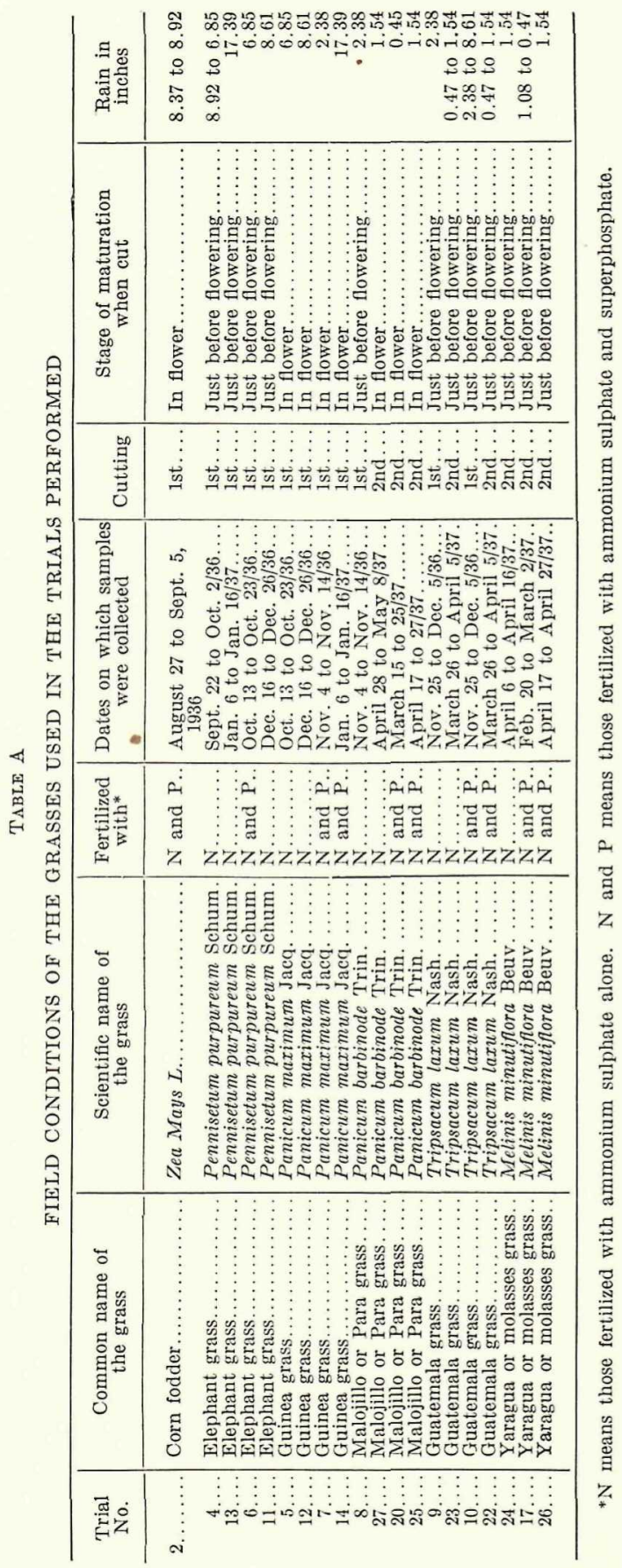


parts of a saturated solution of methyl red in 50 per cent alcohol and one part of a 0.25 per.cent methylene blue solution in water as an indicator to titrate the standard acid in which the ammonia was collected against the standard base. A freshly prepared solution was used whenever titrations were performed. This indicator mixture has the advantage of giving a very sharp end point, changing from violet on the acid side to green on the alkaline side.

An artificial ration having the following composition was given to the animals during the trials performed for determining the minimum protein required for maintenance:

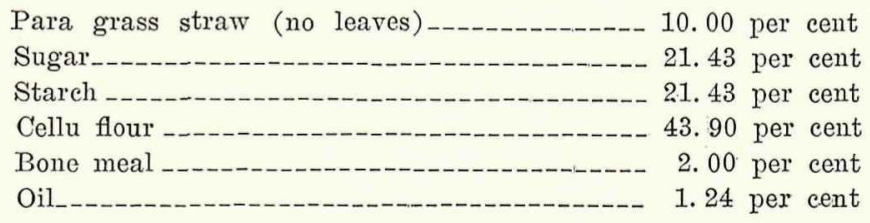

Group A and Group B of our animals became used in this diet after a short time and ate an average of about 400 grams of it per day. The animals of Group D and Group E never became used to it, preferring rather to starve. Due to this, we ran only four trials on this low protein diet; three with animals in Group A and one with animals in Group B. We have calculated the body nitrogen in the feces per gram of dry matter ingested and the body nitrogen in the urine per kilogram of body weight from the data obtained from these trials. The average value obtained from these four trials was applied to all our animals.

Existing data indicates that the body nitrogen in the feces per gram of the dry matter ingested and the body nitrogen in the urine per kilogram of the body weight for sheep receiving a low nitrogen ration is quite uniform. We include the results obtained by other investigators as well as by ourselves for the low protein trials, in table 3 . These results are quite close if we consider the different breeds of animals used.

\section{Results}

Table no. 1 records the percentage content of nitrogen in the feed consumed, the refuse left, and the feces and urine eliminated. These values are later used in the determination of the biological values of the grasses.

Table no. 2 gives the data gathered during the four ten-day metabolism experiments in which the nearly nitrogen-free rations were fed. The average values obtained for the body nitrogen in 
the feces per gram of dry matter ingested and the body nitrogen in the urine per kilogram of body weight are 0.043 grams and 0.526 grams of nitrogen respectively. We have applied these average values in computing all our calculations for the biological values of the proteins.

Table 3 reports the values for body nitrogen in the feces per gram of dry matter ingested and body nitrogen in the urine per kilogram of body weight obtained by other investigators as well as by us.

Table 4 gives a summary of the metabolism experiments upon which the determinations of the biological values of the protein in the grasses are based. "Body Nitrogen Feces" is obtained by multiplying the weight of the total dry feed intake by the body nitrogen in feces per gram of dry matter ingested; while the "Body Nitrogen in Urine" is obtained by multiplying the average "body weight of the animal in kilograms by the body nitrogen in urine per kilogram. of body weight. The percentage of the total protein absorbed through the intestine and retained in the body is called the "Biological Value" of the protein. This value is computed from the following equation: Biological value $=$

100 Food $\mathrm{N}$-'Total $\mathrm{N}$ in feces-Body $\mathrm{N}$ in feces)-(Total $\mathrm{N}$ in urine-Body $\mathrm{N}$ in urin Food $\mathrm{N}$-(Total $\mathrm{N}$ in feces-Body $\mathrm{N}$ in feces)

$$
100 \frac{\text { Food } N \text { retained }}{\text { Food } N \text { absorbed }}
$$

Table 5 contains all the proximate analyses of the offered and refused portions of the rations used in the different experiments. These analyses are all reported on a dry basis. Protein throughout this work is understood to be the nitrogen value multiplied by the factor 6.25.

Table 6 gives the proximate analyses of the feces eliminated during the different trials. These analyses are also given on a dry basis.

The coefficients of apparent digestibilty are given in table 7 . By this coefficient we mean the percentage of the substances in the feed eaten that is absorbed in the intestinal tract. Coefficients of apparent digestibility of dry matter, fat, carbohydrate, ash and organic matter have been calculated. These coefficients are computed with the following equation:

Coefficient of apparent digestibility $=$ 100 Substance in the feed fed-Substance in the feces eliminated Substance in the feed fed 
Table 8 gives the digestible nutrient in 100 pounds of feedstuff on the wet basis in addition to the nutritive ratio of each ration (5). The digestible fats, carbohydrates and proteins are obtained by multiplying the total amount of each nutrient in 100 pounds of the feed by the apparent coefficient of digestibility for that nutrient, as given in table 7 .

The second term of the nutritive ratio is calculated by means of the following formula:

The second term of the nutritive ratio $=$

$\underline{\text { (Digestible fat } \times \text { heat equivalent }=2.25)+ \text { Digestible carbohydrates }}$ Digestible crude protein

A feed or ration having much crude protein in proportion to the carbohydrate and fat combined is said to have a narrow nutritive ratio. If the opposite is true it is said to have a wide nutritive ratio.

Table 9 gives the proximate and ash analyses of the grasses investigated, these determinations being reported on the wet basis, while table 10 contains the same data after having been calculated on the dry basis.

Table 11 is a summary of all the coefficients calculated from the data obtained in this investigation.

The vitamin A activity determinations are recorded in table 12.

\section{DisCUSSTON}

The biological values of the grasses studied do not show great differences if we are to judge these from the results obtained and indicated in the tables.

The proteins of all these grasses seem to be utilized by the lambs with the same efficiency. A significant low result was obtained in Trial No. 6 when elephant grass of the first cutting, fertilized with nitrogen and phosphorus, was fed. The biological value computed for this grass is 69 . In the other three trials performed with this grass, much higher results were obtained, viz., 81, 80 and 80 ; nevertheless, these four samples of elephant grass recorded the lowest biological values obtained in all of the grasses investigated. Two rations of the grass fed to the animals had been fertilized with nitrogen and phosphorus. All of them were from the first cuttings. On the other hand, the malojillo or Para grass has given the highest biological value, viz., $88,97,89$ and 91 . The first value corresponds to a grass from a first cutting fertilized with nitrogen only; the other three were grasses from the second cuttings, one fertilized with nitrogen only and the other two with nitrogen and phosphorus. 
The other four grasses investigated gave values which fall within the rang'e of those obtained for elephant and Para grasses.

The data obtained in these experiments seem to indicate that the biological value is not greatly influenced by the addition of phosphorus as fertilizer or by the cutting. We can conclude, on the basis of the results obtained, that the quality of the protein is inherent in the type of grass, since very similar results were obtained for the same grass in first or second cuttings, and when fertilized with nitrogen or nitrogen and phosphorus.

The trials in which Guatemala grass was fed yielded the highest values obtained for the average coefficients of apparent digestibility for the dry matter, the lowest values obtained corresponded to the Yaragua grass. In the case of the coefficients for crude protein, Para grass trials of first cutting grass recorded the highest value, while the three trials with Yaragua grass yielded the lowest results. The other three trials with Para grass of second cuttings were significantly low, running second to the Yaragua grass trial results. The results obtained with second cutting Para grass seem to indicate that the cuttings exert a significant influence upon the digestibility of the protein. It is interesting to note that all the samples of Yaragua grass tested were from second cuttings and that they contained the least digestible proteins of all the grasses studied. Whether this low index of digestibility is inherent to the grass or is due to the cutting cannot be stated with certainty, since only second cuttings of this grass were tested. This grass also recorded very low coefficients of apparent digestibility for ash. These low values may be due either to the fact that the mineral constituents are not as readily absorbed as in the case of the other grasses or to a lack of palatability of the Yaragua grass, which is the least palatable of all the grasses investigated. Consequently, the animals consumed less of this grass during the ten-day experimental periods than the average weights eaten during similar trials with the other grasses. The total intake of mineral matter then was not enough to supply the output. This second explanation seems to us to be the most plausible one. Palatability is unquestionably an important factor which also has to be considered, as it may greatly influence the nutritive indexes. It is quite apparent that the addition of phosphorus to the fertilizer does not seem to influence the apparent coefficients of digestibility to any great extent.

The nutritive ratios show wide variations. Yaragua grass gives a very wide nutritive ratio, as is to be expected, for it has a low protein coefficient of apparent digestibility. As a matter of fact, 
the nutritive ratio obtained in Trial No. 24 for this grass is extremely wide due to the very low digestibility of the protein. The values for the other two trials with this grass, although wide, are within reasonable limits. The nutritive ratio for corn fodder shows the narrowest value of all. The other grasses give values a little wider than those obtained for fresh green roughage in the United States.

Second cutting grasses recorded nutritive ratios which were always wider than those of the first cutting grasses. This is most probably clue to the fact that the second cutting grasses yield, on a wet basis, lower percentages of protein than first cutting grasses. The fat and carbohydrate contents of second eutting grasses are higher than those for the first cutting grasses.

The chemical analyses of the grasses show some interesting facts. The protein contents vary, when the analyses are calculated on the dry basis, from 9.50 per cent for corn fodder, first cutting fertilized with nitrogen and prosphorus, to 2.61 per cent for Yaragua grass, second cutting, fertilized with nitrogen only. All second cutting grasses show lower protein contents than first cutting grasses. The same is true of the fat The nitrogen-free extract, on the contrary, is always greater in second cutting than in first cutting grasses. Guinea grass shows a higher calcium content than the other grasses; Guatemala grass gives the lowest result. Yaragua grass shows the highest per cent of crude fiber. The phosphorus contents of these grasses seem to be quite constant. The addition of phosphorus to the fertilizer has not shown any appreciable effect on the phosphorus contents of the grasses.

No conclusive results can be obtained from these series of experiments. We have considered only the two factors, fertilizer and cutting, in this discussion, but there is still a third which we have not touched on. This factor is the stage of maturity at which the grasses were cut and eaten by the experimental animals. As will be seen from the table of field conditions presented under the heading "Materials and Methods" at the beginning of this paper, some of the grasses sent to us were cut before the flowering stage and others, during the flowering stage. The stage of maturity at which the grasses are cut affects their nutritive values; therefore, this factor has to be studied separately, and will be, in further experiments.

\section{SUMMARY}

1. Twenty metabolic experiments with grasses cut at different p.eriods, between August 1936 and May 1937, are reported.

2. The biological values were determined for these grasses; the 
highest recorded values belonging to Para grass and the lowest values to elephant grass.

3. The coefficients of apparent digestibility for Yaragua and malojillo grasses of second eutting are quite low.

4. All the grasses tend to give wide nutritive ratios, but Yaragua and malojillo, second cutting grasses, give exceptionally wide ones.

5. Yaragua grasses show a higher fiber content than any of the other grasses investigated.

6. Guinea grass yields, on analysis, significantly high values for calcium; Guatemala grass yielding the lowest values for this element in all the grasses studied.

7. First cuttings of grasses usually yield higher percentages of protein than second cuttings. The same is true of the fat. The nitrogen-free extract, on the contrary, is lower in first cutting than in second cutting grasses.

8. The addition of phosphorus to the fertilizer does not seem to influence to any great extent the nutritive indexes of the grasses studied.

9. The vitamin A activity of the leaves of the grasses has been determined.

\section{BIBLIOGRAPHY}

1. Mitchell, H. H. A Method of Determining the Biological Value of Protein. Jour. Biol. Chem. 58: 873-922. 1924.

2. Sotola, J. Biological Values and Supplementary Relations of the Proteins in Alfalfa Hay and in Corn and Sunflower Silage. Jour. Agric. Res. 40:70-96. 1930.

3. Armsey, H. P. The Nutrition of Farm Animals (1917). Quoted from Sotola, Jour. Agric. Res. 35:366. 1927.

4. Sotola, J. Relation of Maturity to the Nutritive Value of First, Second and Third Cuttings of Irrigated Alfalfa. Jour. Agric. Res. 35: 361-383. 1927.

5. Henry, W. H. and Morrison, F. B. Feeds and Feedings. Eighteenth Edition, p. 40. The Henry-Morrison Co., Madison, Wisconsin.

6. Turk, K. L., Morrison, F. B. \& Maynard, L. A. The Nutritive Value of the Proteins of Alfalfa Hay and Clover Hay when Fed Alone and in Combination with the Proteins of Corn. Joun. Agric. Res. 48: 555-570. 1934.

7. Miller, J. I., Morrison, F. B. and Maynard, L. A. Relative Efficiency for Growing Lambs of the Protein in Rations Supplemented by Soybena-Oil Meal, Linseed Meal or Corn-Gluten Meal. Jour. Agric. Res. 54: 437-448. 1937. 
THE NUTRITIVE VALUES OF SOME FORAGE CROPS OF P. R.

TABLE 1

PER CENT NITROGEN IN FEED FED, REFUSE LEFT, FECES \& URINE

(FEED, REFUSE AND FECES ANALYSES, PER CENT ON DRT BASIS.)

(URINe ANALYSES, PER CENT BY VOLUME.)

\begin{tabular}{|c|c|c|c|c|c|c|}
\hline $\begin{array}{l}\text { Trial } \\
\text { No. }\end{array}$ & Ration & $\begin{array}{l}\text { Nitrogen } \\
\text { in } \\
\text { Feed Fed } \\
\qquad .\end{array}$ & $\begin{array}{c}\text { Nitrogen } \\
\text { in Refuse } \\
\text { Left } \\
q\end{array}$ & Animal & $\begin{array}{c}\text { Nitrogen } \\
\text { in Feces } \\
q\end{array}$ & $\begin{array}{c}\text { Nitrogen } \\
\text { in Urine } \\
\%\end{array}$ \\
\hline $1 \ldots \ldots$ & Low protein diet Formula I.. & 0.17 & n......... & $\begin{array}{l}1 \mathrm{~A} \ldots \\
2 \mathrm{~A} \ldots \\
3 \mathrm{~A} \ldots\end{array}$ & $\begin{array}{l}0.69 \\
0.99 \\
0.91\end{array}$ & $\begin{array}{l}0.14 \\
0.18 \\
0.20\end{array}$ \\
\hline $2 \ldots \ldots$ & Corn fodder ( $N$ and $P$ ) first. & 1.52 & 1.30 & $\begin{array}{l}1 \mathrm{~A} \ldots \\
2 \mathrm{~A} \ldots \\
3 \mathrm{~A} \ldots\end{array}$ & $\begin{array}{l}1.51 \\
1.47 \\
1.38\end{array}$ & $\begin{array}{l}0.24 \\
0.30 \\
0.28\end{array}$ \\
\hline $3 \ldots$ & Low protein diet Formula I.. & 0.23 & $\cdots \cdots \cdots$ & $\begin{array}{l}1 \mathrm{~B} \ldots \\
2 \mathrm{~B} \ldots \\
3 \mathrm{~B} \ldots \\
\end{array}$ & $\begin{array}{l}0.84 \\
0.92 \\
1.05\end{array}$ & $\begin{array}{l}0.60 \\
0.37 \\
0.17\end{array}$ \\
\hline $4 \ldots \ldots$ & Elephant grass ( $\mathrm{N}$ only) first. & 0.81 & 0.34 & $\begin{array}{l}1 \mathrm{~A} \ldots \\
2 \mathrm{~A} \ldots \\
3 \mathrm{~A} \ldots\end{array}$ & $\begin{array}{l}1.06 \\
1.07 \\
1.03\end{array}$ & $\begin{array}{l}0.26 \\
0.34 \\
0.23\end{array}$ \\
\hline $13 \ldots \ldots$ & Elephant grass ( $\mathrm{N}$ only) first.. & 0.87 & 0.40 & $1 \mathrm{~B} \ldots$ & 1.01 & 0.18 \\
\hline $6 \ldots \ldots$ & $\begin{array}{l}\text { Elephant grass }(N \text { and } P) \ldots \\
\text { first }\end{array}$ & 0.72 & 0.37 & $\begin{array}{l}1 \mathrm{~A} \ldots \\
2 \mathrm{~A} \ldots \\
3 \mathrm{~A} \ldots\end{array}$ & $\begin{array}{l}1.09 \\
1.17 \\
1.07\end{array}$ & $\begin{array}{l}0.28 \\
0.43 \\
0.32\end{array}$ \\
\hline $11 \ldots \ldots$ & $\underset{\text { first }}{\text { Elephant grass ( } N \text { and } P \text { ).... }}$ & 1.20 & 0.52 & $\begin{array}{l}1 \mathrm{~B} \ldots \\
2 \mathrm{~B} \ldots \\
3 \mathrm{~B} \ldots\end{array}$ & $\begin{array}{l}1.14 \\
1.19 \\
1.08\end{array}$ & $\begin{array}{l}0.13 \\
0.13 \\
0.15\end{array}$ \\
\hline $5 \ldots \ldots$ & $\begin{array}{l}\text { Guinea grass ( } N \text { only)........ } \\
\text { first }\end{array}$ & 0.94 & 0.62 & $\begin{array}{l}1 \mathrm{~B} \ldots \\
2 \mathrm{~B} \ldots \\
3 \mathrm{~B} \ldots \\
\end{array}$ & $\begin{array}{l}0.95 \\
0.92 \\
0.93\end{array}$ & $\begin{array}{l}0.35 \\
0.47 \\
0.42\end{array}$ \\
\hline $12 \ldots \ldots$ & $\begin{array}{l}\text { Guinea grass ( } N \text { only) ........ } \\
\text { first }\end{array}$ & 0.87 & 0.40 & $\begin{array}{l}1 \mathrm{~A} \ldots \\
2 \mathrm{~A} \ldots \\
3 \mathrm{~A} . \ldots\end{array}$ & $\begin{array}{l}0.97 \\
1.08 \\
1.08\end{array}$ & $\begin{array}{l}0.23 \\
0.27 \\
0.30\end{array}$ \\
\hline $7 \ldots$ & $\underset{\text { first }}{\text { Guinea grass }(N \text { and } P) \ldots . . .}$ & 0.96 & 0.73 & $\begin{array}{l}1 \mathrm{~B} \ldots \\
2 \mathrm{~B} \ldots \\
3 \mathrm{~B} \ldots\end{array}$ & $\begin{array}{l}0.99 \\
0.99 \\
0.96\end{array}$ & $\begin{array}{l}0.35 \\
0.36 \\
0.45\end{array}$ \\
\hline $14 \ldots$ & $\underset{\text { first }}{\text { Guinea grass }}(\mathrm{N}$ and $\mathrm{P}) \ldots \ldots$ & 0.83 & 0.46 & $\begin{array}{l}1 \mathrm{~A} \ldots \\
2 \mathrm{~A} \ldots \\
3 \mathrm{~A} \ldots\end{array}$ & $\begin{array}{l}1.01 \\
1.02 \\
0.99\end{array}$ & $\begin{array}{l}0.18 \\
0.34 \\
0.25\end{array}$ \\
\hline $8 \ldots \ldots$ & $\begin{array}{l}\text { Malojillo grass (N only)....... } \\
\text { first cutting }\end{array}$ & 1.06 & 0.52 & $\begin{array}{l}1 \mathrm{~A} \ldots \\
2 \mathrm{~A} \ldots \\
3 \mathrm{~A} \ldots\end{array}$ & $\begin{array}{l}1.28 \\
1.37 \\
1.21\end{array}$ & $\begin{array}{l}0.21 \\
0.29 \\
0.24\end{array}$ \\
\hline $27 \ldots \ldots$ & $\begin{array}{l}\text { Malojillo grass ( } N \text { only)....... } \\
\text { second cutting }\end{array}$ & 0.50 & 0.38 & $\begin{array}{l}1 \mathrm{~A} \ldots \\
2 \mathrm{~A} \ldots \\
3 \mathrm{~A} \ldots\end{array}$ & $\begin{array}{l}1.02 \\
0.89 \\
0.81\end{array}$ & $\begin{array}{l}0.48 \\
0.52 \\
0.38\end{array}$ \\
\hline $20 \ldots \ldots$ & $\begin{array}{l}\text { Malojillo grass ( } N \text { and } \mathrm{P}) \ldots . . \\
\text { second cutting }\end{array}$ & 0.62 & 0.30 & $\begin{array}{l}1 \mathrm{~A} \ldots \\
2 \mathrm{~A} \ldots \\
3 \mathrm{~A} \ldots\end{array}$ & $\begin{array}{l}1.00 \\
1.01 \\
1.05\end{array}$ & $\begin{array}{l}0.19 \\
0.40 \\
0.37\end{array}$ \\
\hline $25 \ldots \ldots$ & $\begin{array}{l}\text { Malojillo grass ( } N \text { and } P) \ldots \\
\text { second cutting }\end{array}$ & 0.44 & 0.34 & $\begin{array}{l}1 \mathrm{D} \ldots \\
3 \mathrm{D} \ldots\end{array}$ & $\begin{array}{l}0.87 \\
0.95\end{array}$ & $\begin{array}{l}0.27 \\
0.51\end{array}$ \\
\hline$\cdots$ & $\begin{array}{l}\text { Guatemala grass ( } \mathrm{N} \text { only).... } \\
\text { first cutting }\end{array}$ & 0.80 & 0.54 & $\begin{array}{l}1 \mathrm{~B} \ldots . . \\
2 \mathrm{~B} \ldots \\
3 \mathrm{~B} \ldots\end{array}$ & $\begin{array}{l}1.12 \\
1.18 \\
1.15\end{array}$ & $\begin{array}{l}0.22 \\
0.19 \\
0.16\end{array}$ \\
\hline $23 \ldots \ldots$ & $\begin{array}{l}\text { Guatemala grass (N only).... } \\
\text { second eutting }\end{array}$ & 0.69 & 0.55 & $\begin{array}{l}1 \mathrm{E} \ldots \\
2 \mathrm{E} \ldots \\
3 \mathrm{E} \ldots\end{array}$ & $\begin{array}{l}1.00 \\
1.05 \\
1.15\end{array}$ & $\begin{array}{l}0.19 \\
0.38 \\
0.22\end{array}$ \\
\hline $10 \ldots \ldots$ & $\begin{array}{l}\text { Guatemala grass ( } N \text { and } P \text { ).. } \\
\text { first cutting }\end{array}$ & 0.83 & 0.43 & $\begin{array}{l}1 \mathrm{~A} \ldots \\
2 \mathrm{~A} \ldots \\
3 \mathrm{~A} \ldots\end{array}$ & $\begin{array}{l}1.34 \\
1.15 \\
1.24\end{array}$ & $\begin{array}{l}0.19 \\
0.17 \\
0.16\end{array}$ \\
\hline
\end{tabular}


TABLE 1-Contiuued

PER CENT NITROGEN IN FEED FED, REFUSE LEFT, FECES \& URINE

(Feed, Refuse aNd feces analyses, PER Cent on DRy Basis.)

(URINE ANALYSES, PER CENT BY VOLUME.)

\begin{tabular}{|c|c|c|c|c|c|c|}
\hline $\begin{array}{l}\text { Trial } \\
\text { No. }\end{array}$ & Ration & $\begin{array}{l}\text { Nitrogen } \\
\text { in } \\
\text { Feed Fed } \\
\qquad\end{array}$ & $\begin{array}{c}\text { Nitrogen } \\
\text { in } \\
\text { Refuse } \\
\text { Left } \\
q_{0}\end{array}$ & Animal & $\begin{array}{c}\text { Nitrogen } \\
\text { in Feces } \\
\end{array}$ & $\begin{array}{c}\text { Nitrogen } \\
\text { in Urine } \\
q\end{array}$ \\
\hline $22 \ldots \ldots$ & $\begin{array}{l}\text { Guatemala grass (N and } \mathrm{P}) . . \\
\text { second cutting }\end{array}$ & 0.74 & 0.58 & $\begin{array}{l}1 \mathrm{D} \ldots \\
3 \mathrm{D} \ldots\end{array}$ & $\begin{array}{l}1.14 \\
1.12\end{array}$ & $\begin{array}{l}0.22 \\
0.21\end{array}$ \\
\hline $24 \ldots \ldots$ & $\begin{array}{l}\text { Yaragua grass ( } \mathrm{N} \text { only)...... } \\
\text { second cutting }\end{array}$ & 0.42 & 0.37 & $\begin{array}{l}1 \mathrm{~A} \ldots \\
2 \mathrm{~A} \ldots \\
3 \mathrm{~A} \ldots\end{array}$ & $\begin{array}{l}1.29 \\
0.95 \\
0.97\end{array}$ & $\begin{array}{l}0.33 \\
0.23 \\
0.29\end{array}$ \\
\hline $17 \ldots \ldots$ & $\begin{array}{l}\text { Yaragua grass ( } \mathrm{N} \text { and } \mathrm{P}) \ldots . . \\
\text { second cutting }\end{array}$ & 0.54 & 0.32 & $\begin{array}{l}1 \mathrm{~A} \ldots \\
2 \mathrm{~A} \ldots \\
3 \mathrm{~A} \ldots\end{array}$ & $\begin{array}{l}0.98 \\
0.86 \\
0.95\end{array}$ & $\begin{array}{l}0.12 \\
0.21 \\
0.21\end{array}$ \\
\hline $26 \ldots \ldots$ & $\begin{array}{l}\text { Yaragua grass }(\mathrm{N} \text { and } \mathrm{P}) \ldots . \\
\text { second cutting }\end{array}$ & 0.49 & 0.33 & $\begin{array}{l}1 \mathrm{E} \ldots \\
2 \mathrm{E} \ldots \\
3 \mathrm{E} \ldots\end{array}$ & $\begin{array}{l}0.98 \\
1.10 \\
1.16\end{array}$ & $\begin{array}{l}0.22 \\
0.34 \\
0.24\end{array}$ \\
\hline $15 \mathrm{~A} \ldots$. & Low protein $\operatorname{diet} . . . \ldots \ldots \ldots$ & 0.12 & & $\begin{array}{l}1 \mathrm{~A} \ldots \\
2 \mathrm{~A} \ldots \\
3 \mathrm{~A} \ldots\end{array}$ & $\begin{array}{l}0.62 \\
0.90 \\
0.94\end{array}$ & $\begin{array}{l}0.10 \\
0.33 \\
0.84\end{array}$ \\
\hline $30 \ldots \ldots$ & 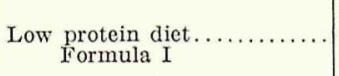 & 0.08 & $\ldots \ldots \ldots \ldots$ & $\begin{array}{l}1 \mathrm{~A} \ldots \\
2 \mathrm{~A} \ldots \\
3 \mathrm{~A} \ldots\end{array}$ & $\begin{array}{l}0.92 \\
0.82 \\
0.80\end{array}$ & $\begin{array}{l}0.11 \\
0.19 \\
0.12\end{array}$ \\
\hline
\end{tabular}

TABLE 2

MAINTENANCE REQUIREMENT OF LAMBS AVERAGING 17.84 KILOGRAMS IN WEIGHT, BODY NITROGEN IN FECES PER GRAM OF DRY MATTER INGESTED

AND BODY NITROGEN IN URINE PER 100 GRAMS OF BODY WEIGHT, BASED ON TEN-DAY TRIALS DURING WHICH NEARLY NITROGEN-FREE RATIONS WERE FED.

\begin{tabular}{|c|c|c|c|c|c|c|c|c|c|}
\hline $\begin{array}{c}\text { Trial } \\
\text { No. }\end{array}$ & $\begin{array}{c}\text { Animal } \\
\mathrm{No} .\end{array}$ & $\begin{array}{c}\text { Average } \\
\text { Weight } \\
\text { Kg. }\end{array}$ & $\begin{array}{c}\text { Dry } \\
\text { Matter } \\
\text { Ingested } \\
\text { Gm. }\end{array}$ & $\begin{array}{l}\text { Nitrogen } \\
\text { in Feed } \\
\text { Consum- } \\
\text { ed } \%\end{array}$ & $\begin{array}{l}\text { Total } \\
\text { Fecal } \\
\text { Nitrogen } \\
\text { Gm. }\end{array}$ & $\begin{array}{c}\text { Total } \\
\text { Urinary } \\
\text { Nitrogen } \\
\text { Gm. }\end{array}$ & 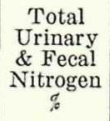 & \begin{tabular}{c}
\multicolumn{1}{c}{ Fecal } \\
Nitrogen \\
Per Gm. of \\
Dry Matter \\
Ingested
\end{tabular} & $\begin{array}{c}\text { Urinary } \\
\text { Nitrogen } \\
\text { Per } 100 \mathrm{Gm} \text {. } \\
\text { Body } \\
\text { Weight }\end{array}$ \\
\hline $1 . \ldots$ & $\begin{array}{l}1-A \ldots \\
2-A . . \\
3-A . .\end{array}$ & $\begin{array}{l}18.35 \\
22.30 \\
18.00\end{array}$ & $\begin{array}{l}4,245 \\
4,225 \\
3,660\end{array}$ & $\begin{array}{l}0.17 \\
0.17 \\
0.17\end{array}$ & $\begin{array}{l}13.80 \\
18.15 \\
15.48\end{array}$ & $\begin{array}{r}12.71 \\
12.40 \\
8.92\end{array}$ & $\begin{array}{l}26.51 \\
30.55 \\
24.40\end{array}$ & $\begin{array}{l}0.0033 \\
0.0043 \\
0.0042\end{array}$ & $\begin{array}{l}0.694 \\
0.556 \\
0.495\end{array}$ \\
\hline $15 \ldots$ & $\begin{array}{l}1-A . . \\
2-A \\
3-A . .\end{array}$ & $\begin{array}{l}17.25 \\
15.85 \\
15.25\end{array}$ & $\begin{array}{l}3,640 \\
2,830 \\
1,686\end{array}$ & $\begin{array}{l}0.12 \\
0.12 \\
0.12\end{array}$ & $\begin{array}{r}11.30 \\
16.71 \\
6.70\end{array}$ & $\begin{array}{l}7.37 \\
6.35 \\
9.15\end{array}$ & $\begin{array}{l}18.67 \\
23.06 \\
15.85\end{array}$ & $\begin{array}{l}0.0048 \\
0.0059 \\
0.0040\end{array}$ & $\begin{array}{l}0.427 \\
0.400 \\
0.600\end{array}$ \\
\hline $30 \ldots$ & $\begin{array}{l}1-A . . \\
2-A . . \\
3-A . .\end{array}$ & $\begin{array}{l}20.48 \\
22.70 \\
20.83\end{array}$ & $\begin{array}{l}2,920 \\
3,180 \\
2,800\end{array}$ & $\begin{array}{l}0.08 \\
0.08 \\
0.08\end{array}$ & $\begin{array}{l}11.98 \\
16.08 \\
10.15\end{array}$ & $\begin{array}{l}9.90 \\
3.62 \\
4.75\end{array}$ & $\begin{array}{l}21.88 \\
19.70 \\
14.90\end{array}$ & $\begin{array}{l}0.0041 \\
0.0051 \\
0.0036\end{array}$ & $\begin{array}{l}0.483 \\
0.159 \\
0.228\end{array}$ \\
\hline 3..... & $\begin{array}{l}1-B \ldots \\
2-B \ldots \\
3-B \ldots\end{array}$ & $\begin{array}{l}11.77 \\
16.55 \\
14.78\end{array}$ & $\begin{array}{l}2,427 \\
3,089 \\
3,401\end{array}$ & $\begin{array}{l}0.23 \\
0.23 \\
0.23\end{array}$ & $\begin{array}{r}9.25 \\
14.22 \\
15.65\end{array}$ & $\begin{array}{r}9.76 \\
10.38 \\
8.35\end{array}$ & $\begin{array}{l}19.01 \\
24.60 \\
24.00\end{array}$ & $\begin{array}{l}0.0038 \\
0.0046 \\
0.0046\end{array}$ & $\begin{array}{l}0.830 \\
0.626 \\
0.565\end{array}$ \\
\hline
\end{tabular}


TABLE 3

VALUES FOR BODY NITROGEN IN FECES PER GRAM OF DRY MATTER INGESTED AND BODY NITROGEN IN URINE PER KILOGRAM OF BODY WEIGHT AS OBTAINED BY DIFFERENT INVESTIGATORS WHEN NEARLY NITROGEN-FREE RATIONS ARE FED TO LAMBS

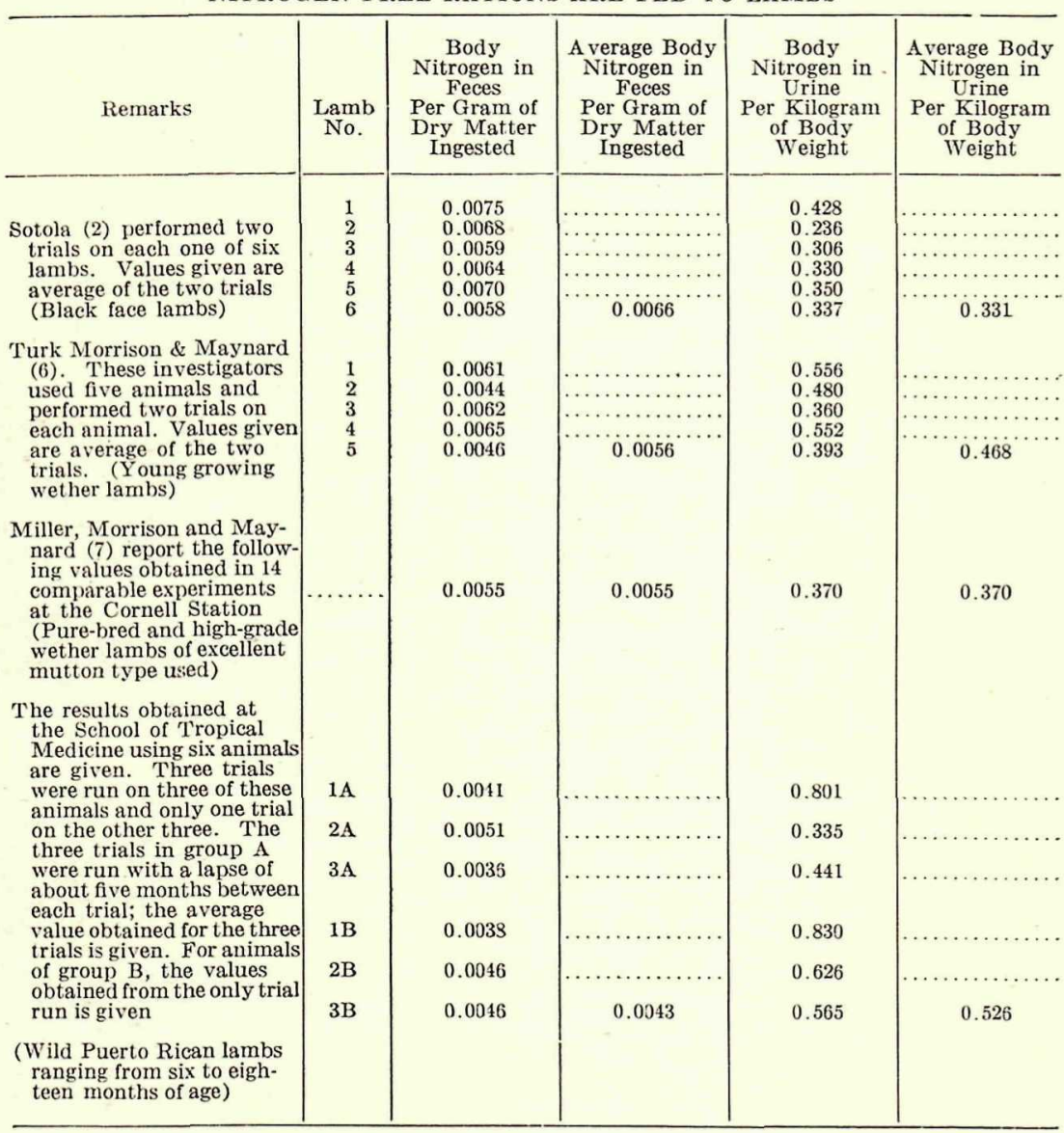




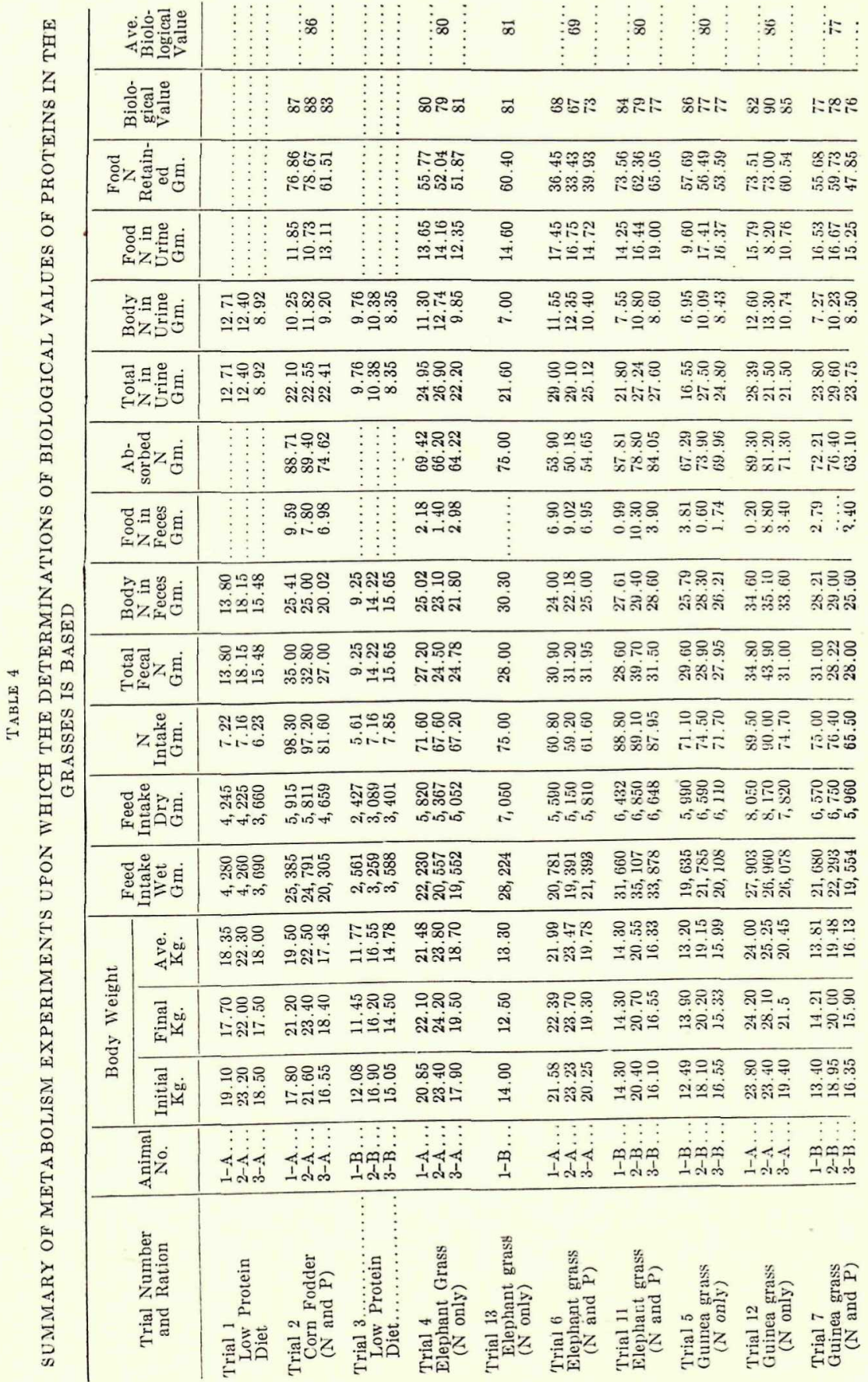




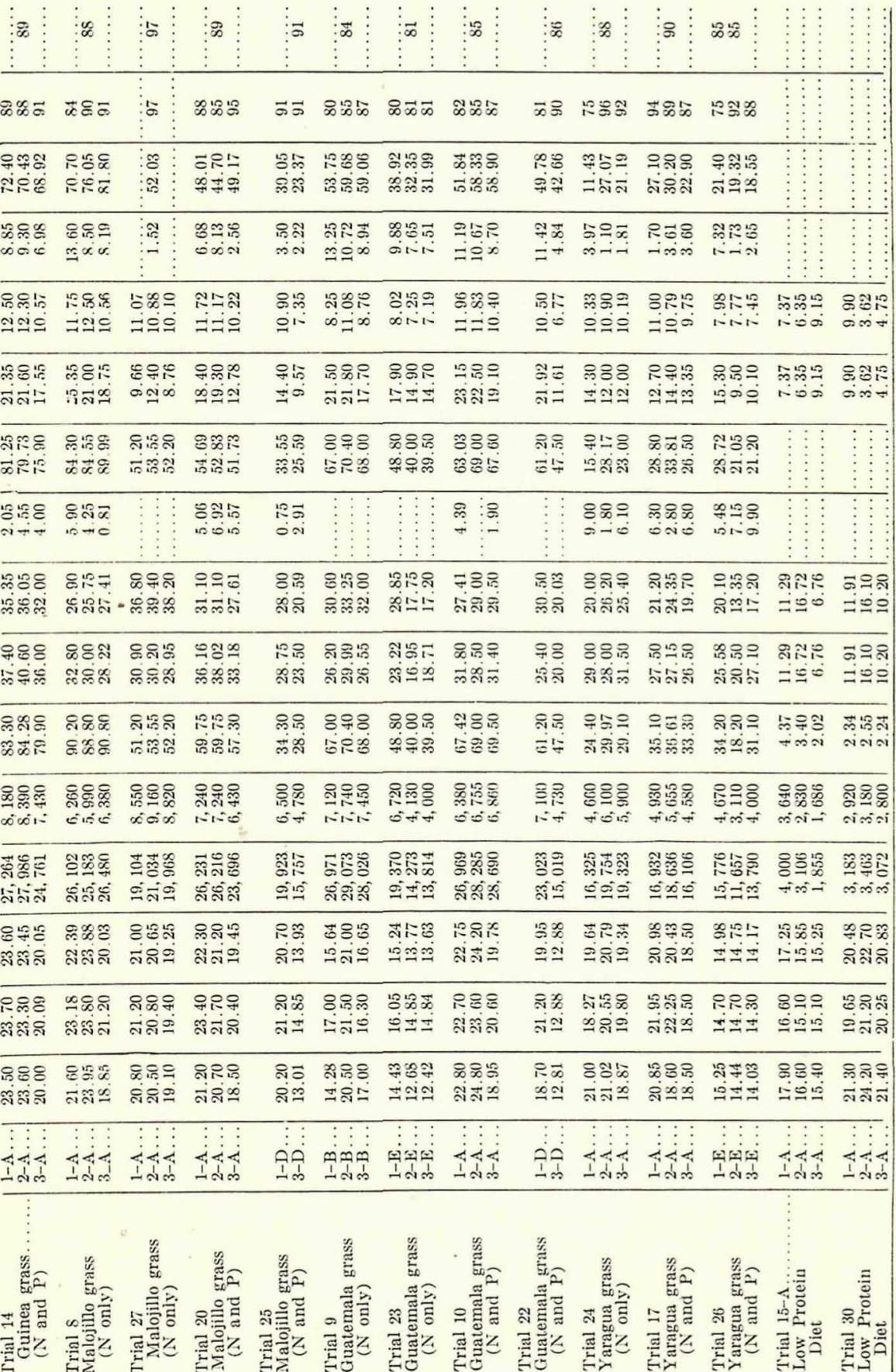




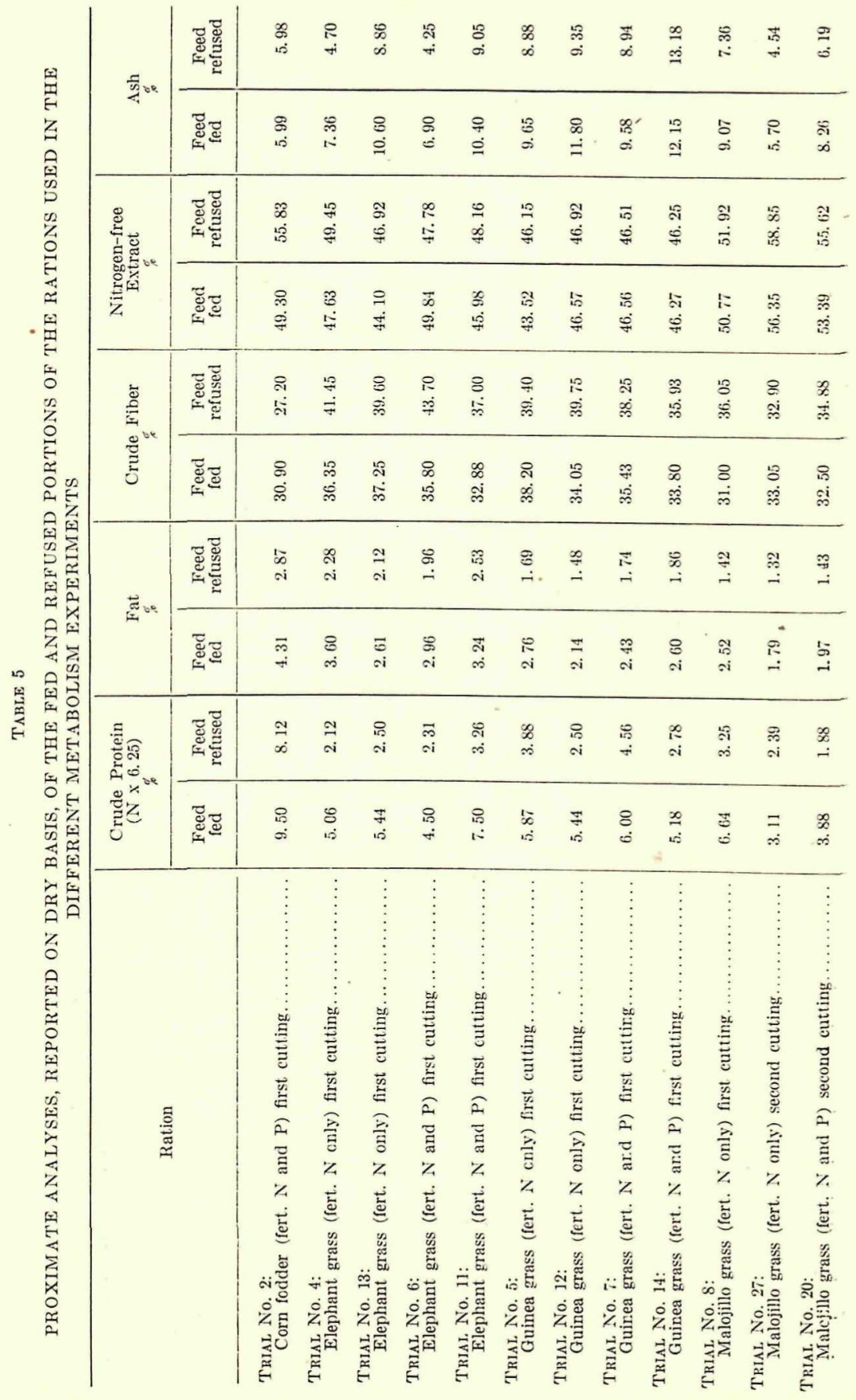


THE NUTRITIVE VALUES OF SOME FORAGE CROI'S ()I I'. R

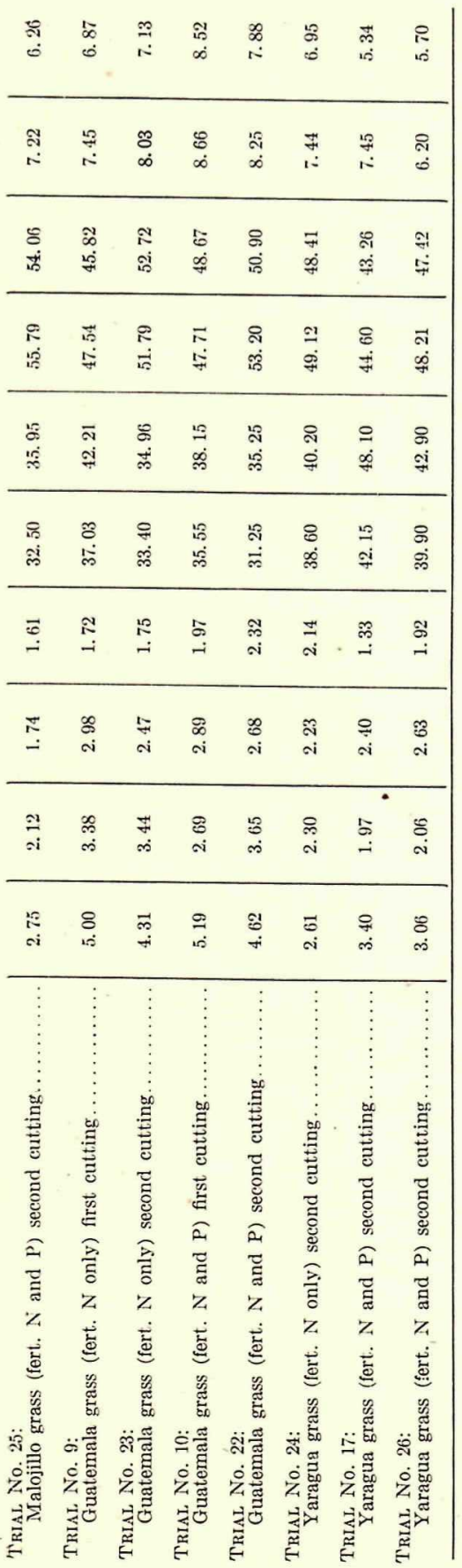


TABLE 6

PROXIMATE ANALYSES OF THE FECES, REPORTED ON DRY BASIS, AVERAGE COMPOSITE SAMPLE OF TEN-DAY METABOLISM EXPERIMENTS

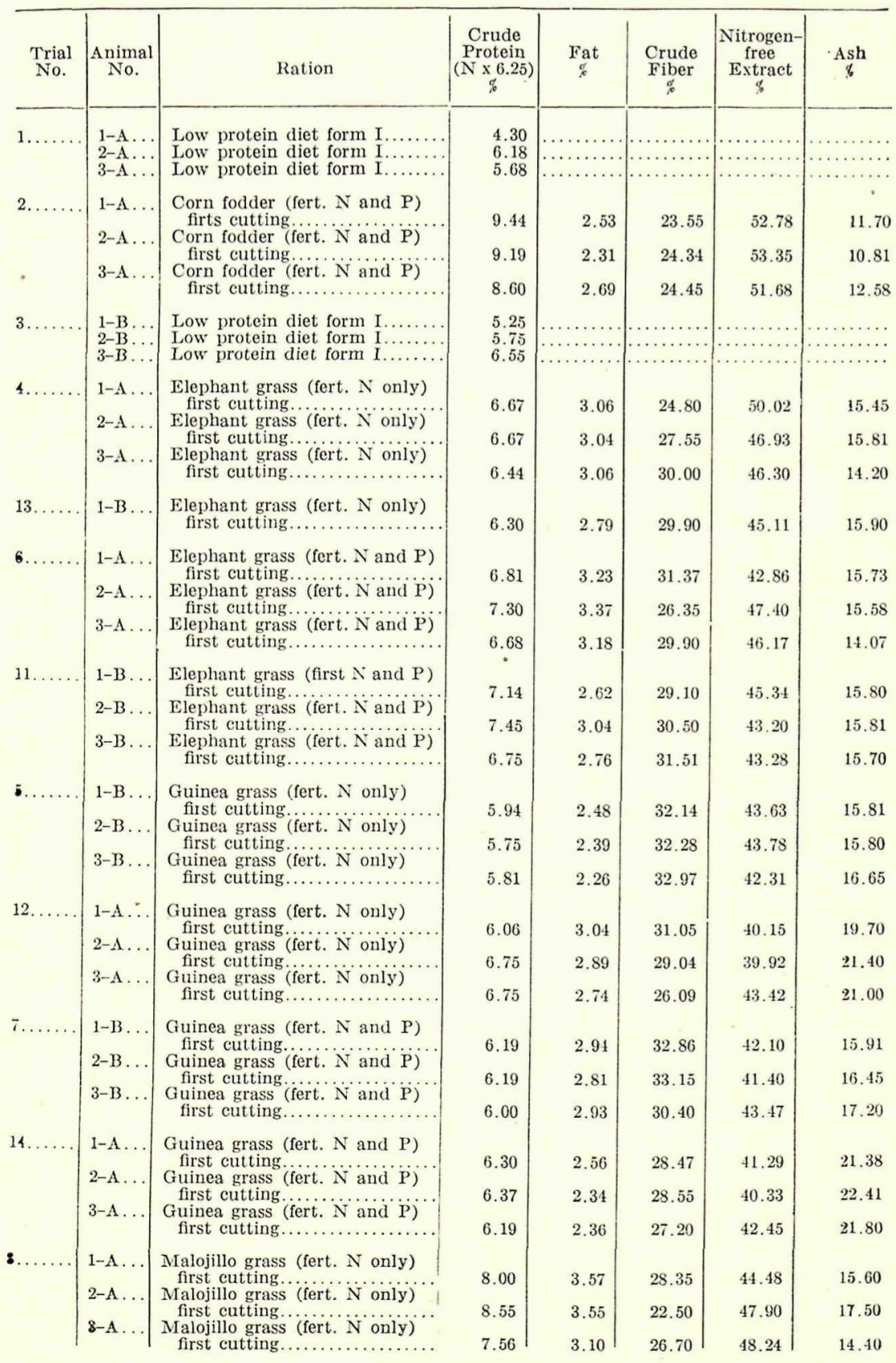


TABLE 6-Continued

PROXIMATE ANALYSES OF THE FECES, REPORTED ON DRY BASIS, AVERAGE COMPOSITE SAMPLE OF TEN-DAY METABOLISM EXPERIMENTS

\begin{tabular}{|c|c|c|c|c|c|c|c|}
\hline $\begin{array}{l}\text { Trial } \\
\text { No. }\end{array}$ & Animal & Ration & $\begin{array}{c}\text { Crude } \\
\text { Protein } \\
(\mathrm{N} \times 6.25) \\
q\end{array}$ & $\underset{g}{\text { Fat }}$ & $\begin{array}{c}\text { Crude } \\
\text { Fiber } \\
\not\end{array}$ & $\begin{array}{c}\text { Nitrogen- } \\
\text { free } \\
\text { Extract } \\
\% \\
\end{array}$ & $\underset{*}{A s h}$ \\
\hline $27 \ldots \ldots$ & $\begin{array}{l}1-A \\
2-A \\
3-A\end{array}$ & 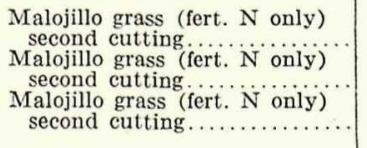 & 5.56 & 1.72 & 33.85 & 48.47 & 10.90 \\
\hline $20 \ldots \ldots$ & $\begin{array}{l}1-A \ldots \\
2-A \ldots \\
3-A \ldots\end{array}$ & 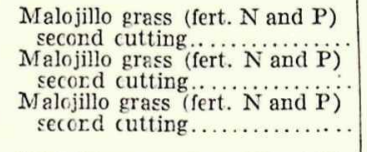 & $\begin{array}{l}6.31 \\
6.56\end{array}$ & $\begin{array}{l}1.92 \\
\text { 1. } 22 \\
\text { 1. } 36\end{array}$ & $\begin{array}{l}30.66 \\
32.70 \\
30.10\end{array}$ & $\begin{array}{l}46.57 \\
46.27\end{array}$ & $\begin{array}{l}14.60 \\
13.50 \\
14.85\end{array}$ \\
\hline $25 \ldots \ldots$ & $\begin{array}{l}1-\mathrm{D} . \\
3-\mathrm{D} .\end{array}$ & 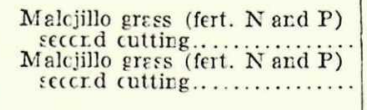 & 5.94 & 1. 82 & 35.30 & 44.04 & $\begin{array}{l}13.50 \\
12.90\end{array}$ \\
\hline 8. . . . & $\begin{array}{l}1-\mathrm{B} \ldots \\
2-\mathrm{B} \ldots \\
3-\mathrm{B} \ldots\end{array}$ & 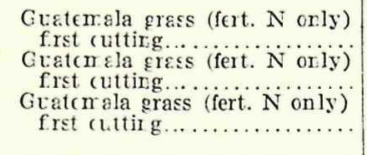 & $\begin{array}{r}7.37 \\
7.19\end{array}$ & $\begin{array}{l}2.28 \\
2.31\end{array}$ & $\begin{array}{l}32.08 \\
30.23\end{array}$ & $\begin{array}{l}45.58 \\
47.87\end{array}$ & $\begin{array}{r}11.95 \\
12.70 \\
12.40\end{array}$ \\
\hline $23 \ldots \ldots$ & $\begin{array}{l}1-\mathrm{E} \ldots \\
2-\mathrm{E} \ldots \\
3-\mathrm{E} . .\end{array}$ & 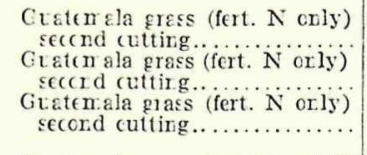 & $\begin{array}{l}6.25 \\
6.56 \\
7.20\end{array}$ & $\begin{array}{l}2.07 \\
2.24 \\
2.30\end{array}$ & $\begin{array}{l}31.21 \\
30.05\end{array}$ & $\begin{array}{l}47.96 \\
45.69 \\
45.20\end{array}$ & $\begin{array}{l}14.30 \\
15.25\end{array}$ \\
\hline $10 \ldots \ldots$ & $\begin{array}{l}1-\mathrm{A} \ldots \\
2-\mathrm{A} \ldots \\
3-\mathrm{A} \ldots\end{array}$ & 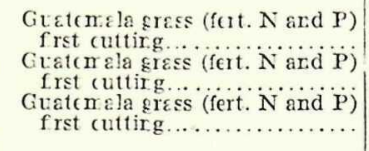 & $\begin{array}{l}8.38 \\
7.19 \\
7.75\end{array}$ & $\begin{array}{l}2.49 \\
2.34\end{array}$ & $\begin{array}{l}32.30 \\
30.95\end{array}$ & $\begin{array}{l}43.53 \\
45.92 \\
45.69\end{array}$ & $\begin{array}{l}13.30 \\
13.60 \\
13.00\end{array}$ \\
\hline $22 \ldots \ldots$ & $\begin{array}{l}1-D \ldots \\
3-D .\end{array}$ & 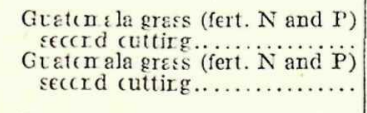 & $\begin{array}{l}7.13 \\
7.60\end{array}$ & $\begin{array}{l}2.19 \\
2.32\end{array}$ & $\begin{array}{l}30.45 \\
29.35\end{array}$ & $\begin{array}{l}45.63 \\
46.13\end{array}$ & $\begin{array}{r}14.60 \\
15.20\end{array}$ \\
\hline $24 \ldots \ldots$ & $\begin{array}{l}1-A \ldots \\
2-A \ldots \\
3-A \ldots\end{array}$ & 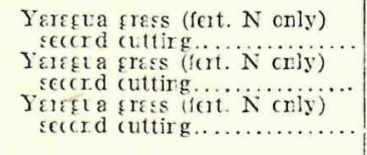 & $\begin{array}{l}8.05 \\
5.94 \\
6.05\end{array}$ & $\begin{array}{l}2.99 \\
2.88 \\
3.22\end{array}$ & $\begin{array}{l}28.73 \\
30.60 \\
30.90\end{array}$ & $\begin{array}{l}44.58 \\
46.18 \\
45.33\end{array}$ & $\begin{array}{r}15.65 \\
14.40 \\
14.50\end{array}$ \\
\hline $17 \ldots \ldots$ & $\begin{array}{l}1 \mathrm{~A} \ldots \\
2-\mathrm{A} \ldots \\
3-\mathrm{A} \ldots\end{array}$ & 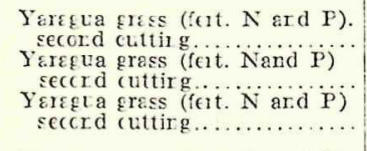 & $\begin{array}{l}6.13 \\
5.37\end{array}$ & $\begin{array}{l}2.56 \\
2.19\end{array}$ & 29.69 & $\begin{array}{l}45.81 \\
46.29 \\
45.89\end{array}$ & $\begin{array}{l}16.30 \\
14.70 \\
16.10\end{array}$ \\
\hline $26 \ldots \ldots$ & $\begin{array}{l}1-\mathrm{E} \ldots \\
2-\mathrm{E} \ldots \\
3-\mathrm{E} \ldots\end{array}$ & 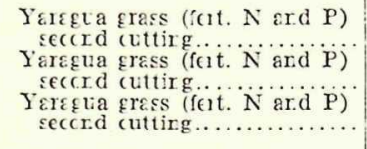 & $\begin{array}{l}6.13 \\
6.87 \\
7.25\end{array}$ & $\begin{array}{l}3.93 \\
3.92 \\
4.10\end{array}$ & $\begin{array}{l}30.50 \\
31.00 \\
29.25\end{array}$ & $\begin{array}{l}44.64 \\
44.81 \\
45.19\end{array}$ & $\begin{array}{l}14.80 \\
13.40 \\
14.21\end{array}$ \\
\hline $15-A \ldots$ & $\begin{array}{l}1-\mathrm{A} \ldots \\
2-\mathrm{A} \ldots \\
3-\mathrm{A} \ldots\end{array}$ & 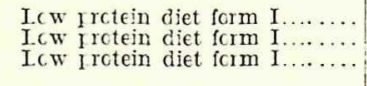 & $\begin{array}{l}3.88 \\
5.62 \\
5.87\end{array}$ & & & & \\
\hline $30 \ldots$ & $\begin{array}{l}1-\mathrm{A} \\
2-\mathrm{A} \\
3-\mathrm{A}\end{array}$ & $\begin{array}{l}\text { Lcw rrctein diet form II ...... } \\
\text { Lcw Irotein diet form II ....... } \\
\text { Lcw Irctein diet form II...... }\end{array}$ & $\begin{array}{l}5.75 \\
5.11 \\
4.97 \\
\end{array}$ & & $\begin{array}{l}\ldots \ldots \ldots \ldots \\
\cdots \ldots \ldots \ldots \ldots \\
\ldots \ldots \ldots \ldots\end{array}$ & $\begin{array}{l}\ldots \ldots \ldots \ldots \\
\ldots \ldots \ldots \ldots \ldots \\
\ldots \ldots \ldots \ldots\end{array}$ & $\begin{array}{l}\ldots \ldots \ldots \ldots \\
\cdots \ldots \ldots \ldots \\
\ldots \ldots \ldots \ldots \\
\end{array}$ \\
\hline
\end{tabular}


114 THE JOURNAL OF AGRICULTURE OF THE UNIVERSITY OF P. R.

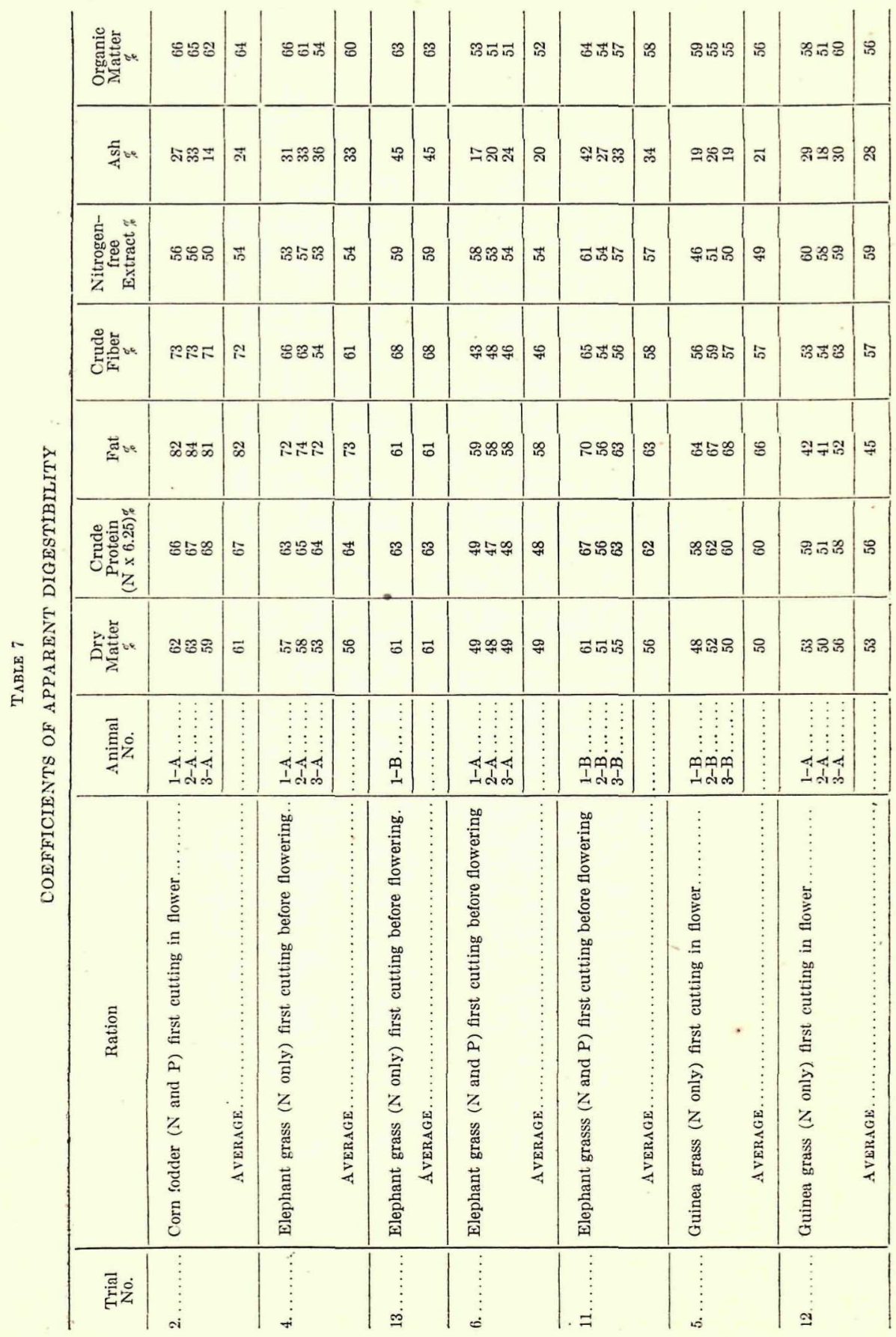


THE NUTRITIVE VALUES OF SOME FORAGE CROPS OF P. R. 115

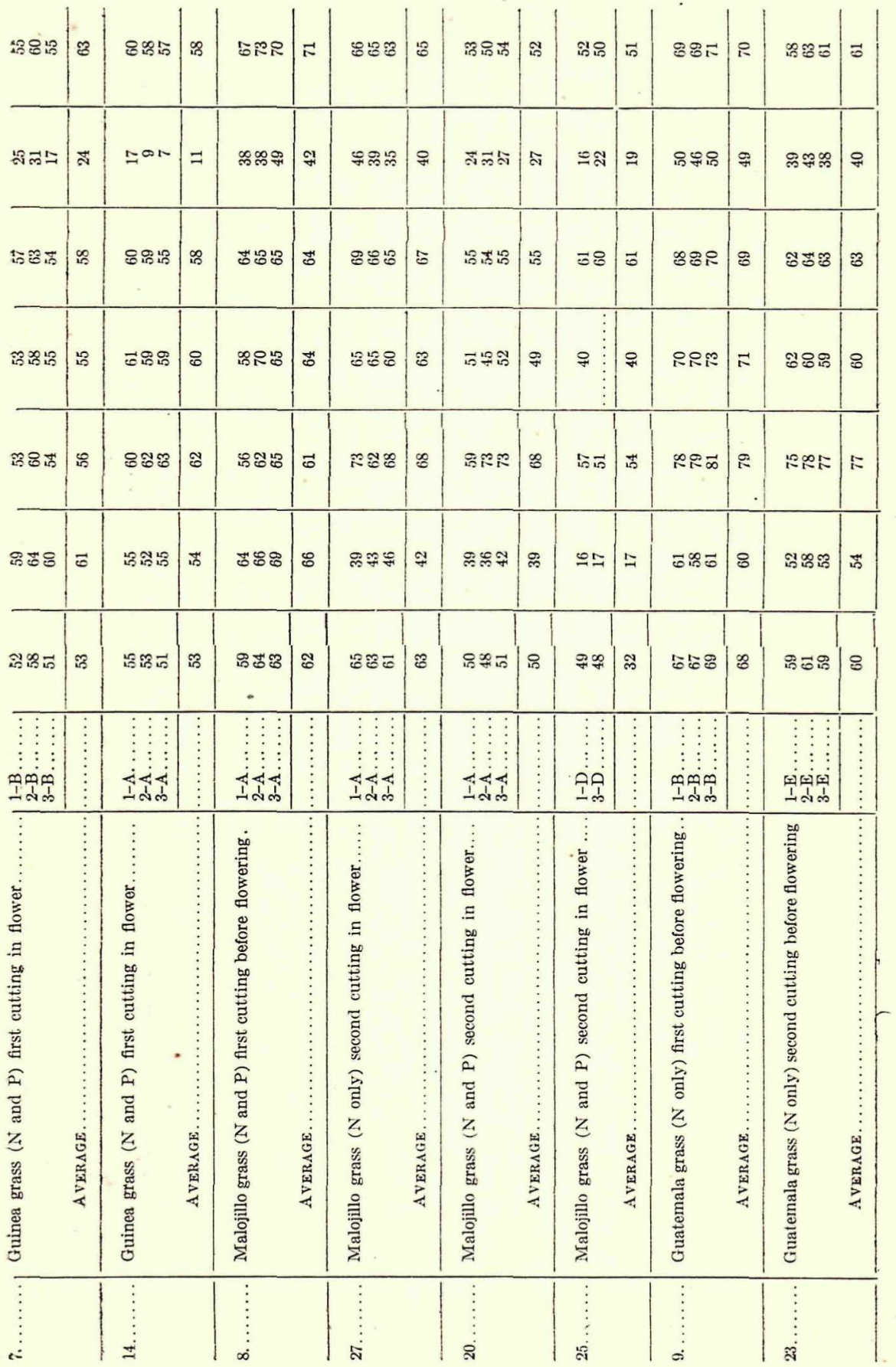




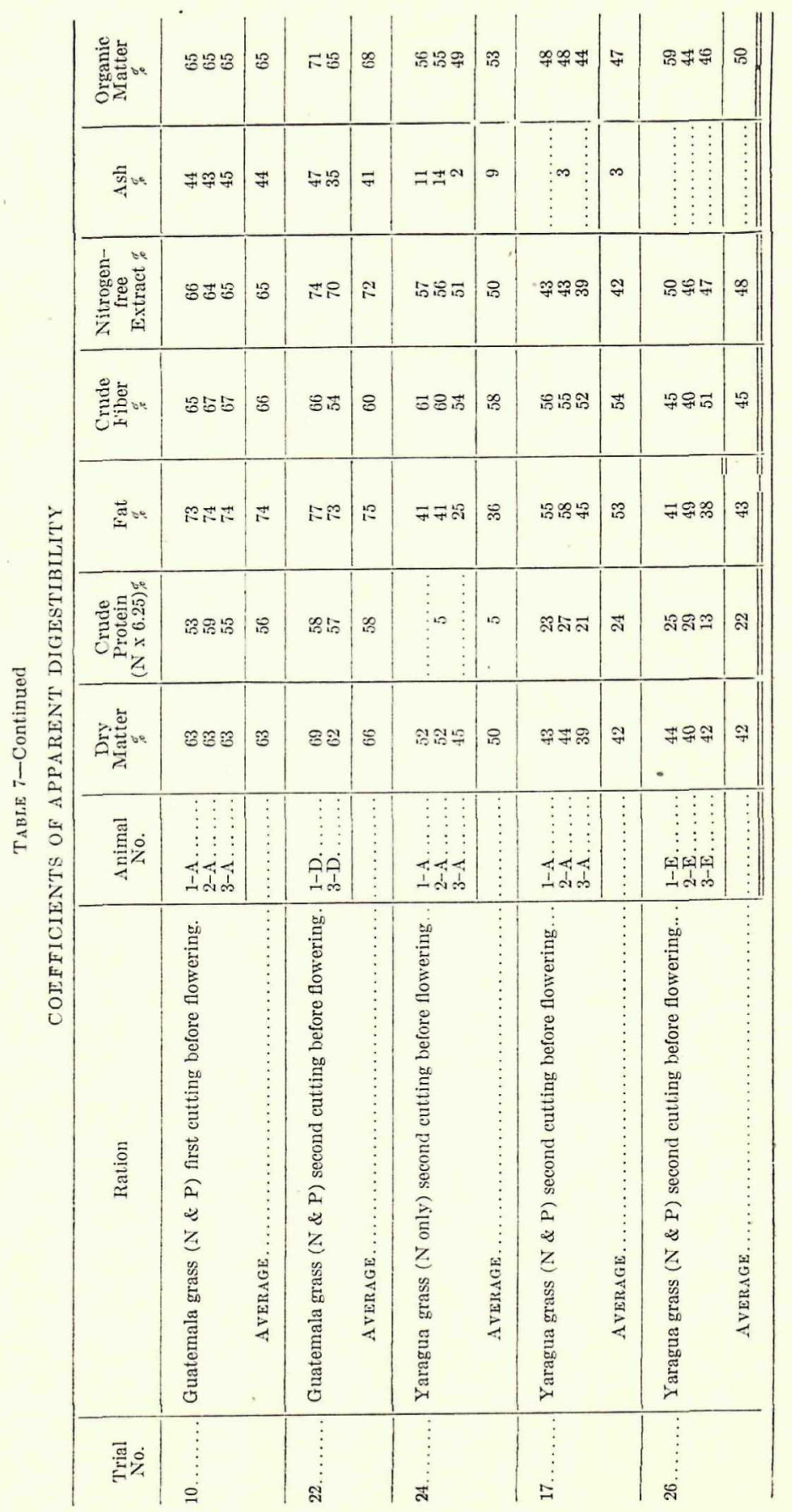


TAble 8

DIGBSTIBLE NUTRIENTS IN 100 LBS. OF PUERTO RICAN FEEDING STUFFS AS CUT

\begin{tabular}{|c|c|c|c|c|c|c|c|}
\hline \multirow{2}{*}{\multicolumn{2}{|c|}{ Feeding stuff }} & \multirow[b]{2}{*}{$\begin{array}{l}\text { Total } \\
\text { dry } \\
\text { matter }\end{array}$} & \multicolumn{4}{|c|}{ Digestible Nutrients } & \multirow[b]{2}{*}{$\begin{array}{l}\text { Nutritive } \\
\text { ratio }\end{array}$} \\
\hline & & & $\begin{array}{l}\text { Crude } \\
\text { Protein }\end{array}$ & Fat & $\begin{array}{c}\text { Carbo- } \\
\text { hydrates }\end{array}$ & $\begin{array}{c}\text { Total } \\
\text { (inc. fat } \\
\times 2.25 \text { ) }\end{array}$ & \\
\hline & $\begin{array}{l}\text { Corn fodder (fert. } \mathrm{N} \text { and } \mathrm{P} \text { ) first } \\
\text { cutting } \ldots \ldots \ldots \ldots \ldots \ldots \ldots \ldots \ldots \ldots \ldots\end{array}$ & 23. 79 & 1.51 & 0.84 & 11.71 & 13.60 & $1: 9.0$ \\
\hline & 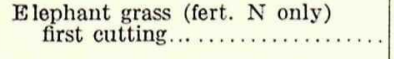 & 27.68 & 0.90 & 0.73 & 13.06 & 14.75 & $1: 16.4$ \\
\hline & 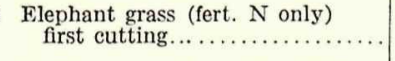 & 24.60 & 0.85 & 0.39 & 12.64 & 13.52 & $1: 16.0$ \\
\hline & 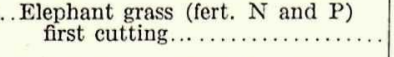 & 30.08 & 0.63 & 0.52 & 13.05 & 14.22 & $1: 22.5$ \\
\hline & 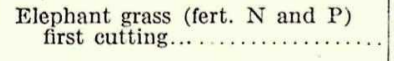 & 19.23 & 0.90 & 0.39 & 8.70 & 9.58 & $1: 10.6$ \\
\hline 5 & 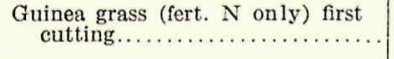 & 29.44 & 1.05 & 0.54 & 12. 20 & 13.42 & $1: 12.8$ \\
\hline 12 & $\begin{array}{l}\text { Guinea grass (fert. } N \text { onl } y) \text { first } \\
\text { cutting } \ldots \ldots \ldots \ldots \ldots \ldots \ldots \ldots \ldots \ldots\end{array}$ & 29.84 & 0. 91 & 0.29 & 14.00 & 14.66 & $1: 16.1$ \\
\hline 7 & 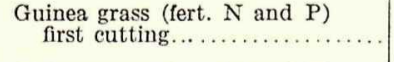 & 29.64 & 1.08 & 0.40 & 13.81 & 14. 71 & $1: 13.6$ \\
\hline 14 & 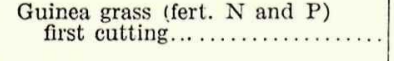 & 30.00 & 0.84 & 0.48 & 14.05 & 15.13 & $1: 18.0$ \\
\hline 8 & $\begin{array}{l}\text { Malojillo grass (fert. } \mathrm{N} \text { only) } \\
\quad \text { first cutting..................... }\end{array}$ & 26. 18 & 1. 15 & 0.40 & 13. 70 & 14.60 & $1: 12.7$ \\
\hline $2 \pi$ & 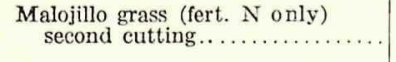 & 37.90 & 0.50 & 0.46 & 22.33 & 23.37 & $1: 46.7$ \\
\hline 20 & 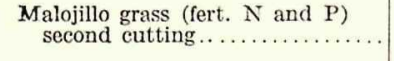 & 29.10 & 0.44 & 0.39 & 12. 27 & 13.15 & $1: 30.0$ \\
\hline 25 & 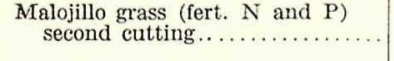 & 34.00 & 0.21 & 0.32 & 17.57 & 18. 29 & $1: 87.0$ \\
\hline 9 & 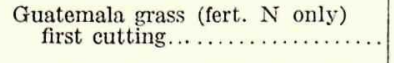 & 27.00 & 0.81 & 0.64 & 15. 20 & 16. 64 & $1: 20.6$ \\
\hline 28 & 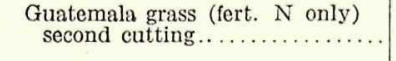 & 30.50 & 0.70 & 0.57 & 16. 40 & 17.68 & $1: 25.2$ \\
\hline 10 & 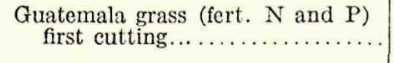 & 24.60 & 0.72 & 0.53 & 13.42 & 14.62 & $1: 20.4$ \\
\hline 22 & 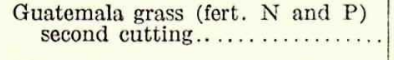 & 30.40 & 0.81 & 0.62 & 17.30 & 18. 70 & $1: 23.1$ \\
\hline 21 & $\begin{array}{l}\text { Yaragua grass (fert. } \mathrm{N} \text { only) } \\
\quad \text { second cutting } . \ldots \ldots \ldots \ldots \ldots \ldots\end{array}$ & 36.30 & 0.05 & 0.29 & 17.08 & 17. 74 & $1: 35.4$ \\
\hline 17 & 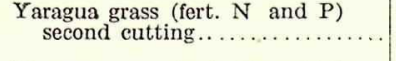 & 34.00 & 0.28 & 0.44 & 14. 13 & 15.12 & $1: 54.0$ \\
\hline 28 & 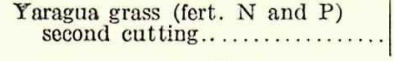 & 34.80 & 0.23 & 0.40 & 14.30 & 15. 20 & $1: 66.2$ \\
\hline
\end{tabular}

Note: "N and P" stands for nitrogen and phosphorus in the fertilizer. " $N$ " stands for nitrogen only in the fertilizer. 
THE JOURNAL OF AGRICULTURE OF THE UNIVERSITY OF P. R.

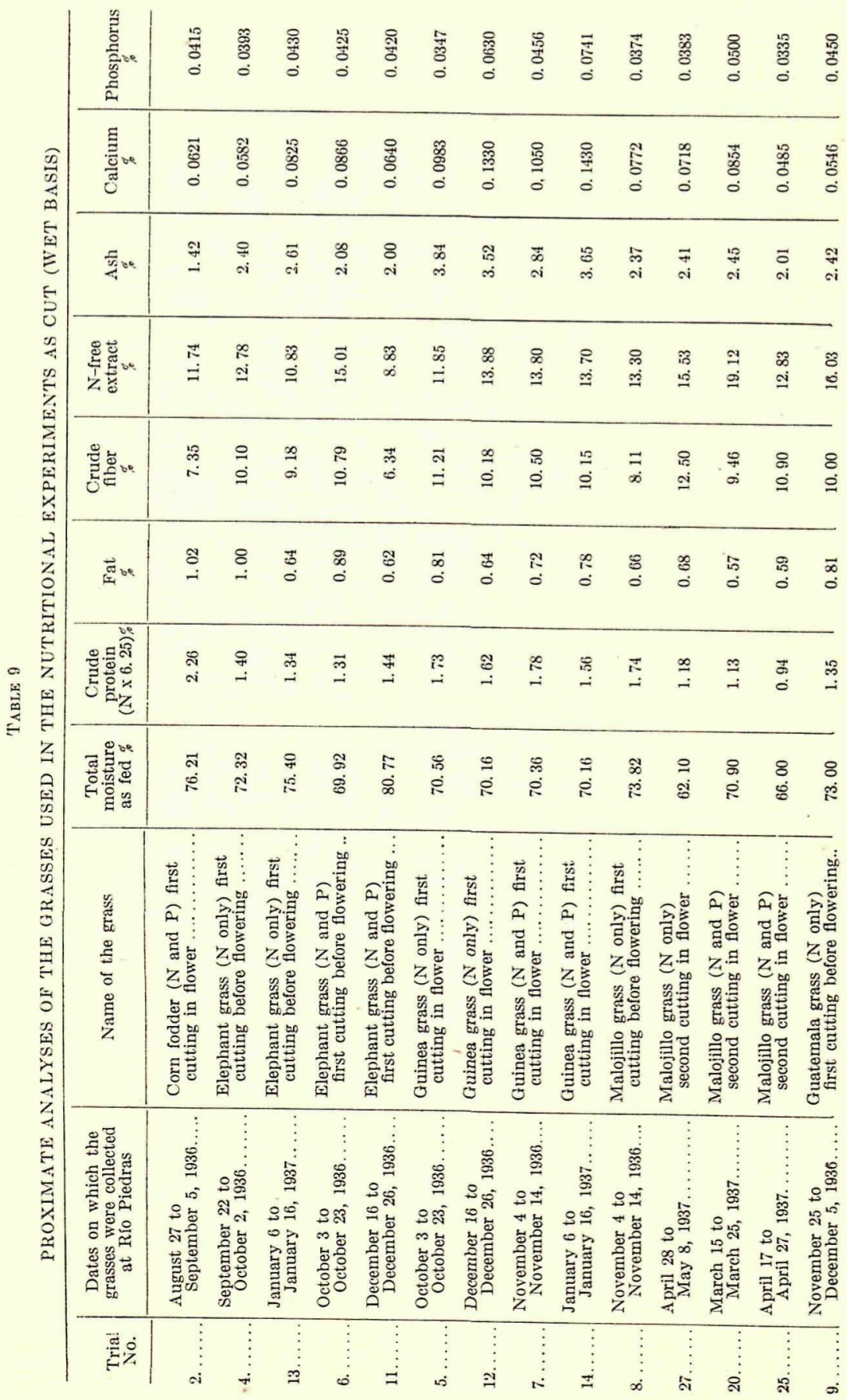


THE NUTRITIVE VALUES OF SOME FORAGE CROPS OF P. R.

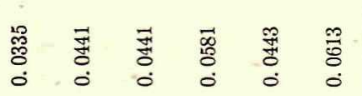

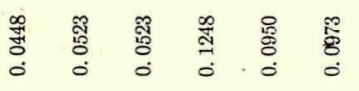

\begin{tabular}{|c|c|c|c|c|}
\hline & in & : & $\stackrel{R}{R}$ & กิ \\
\hline & oi & Ni & N & ง \\
\hline
\end{tabular}

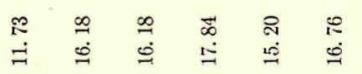

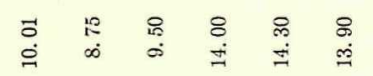

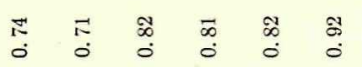

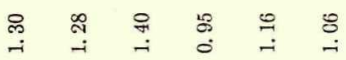

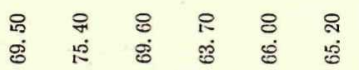

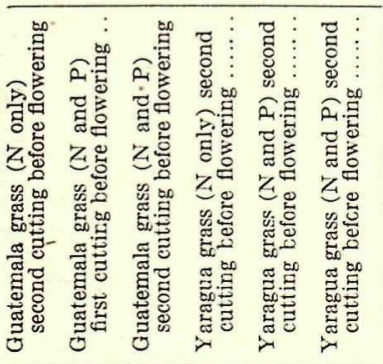

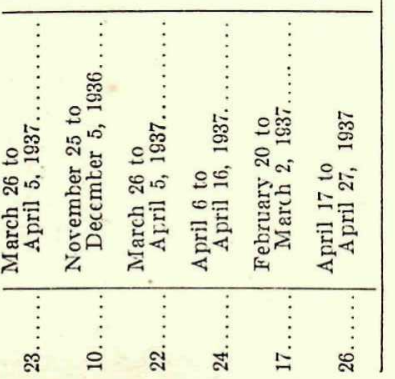

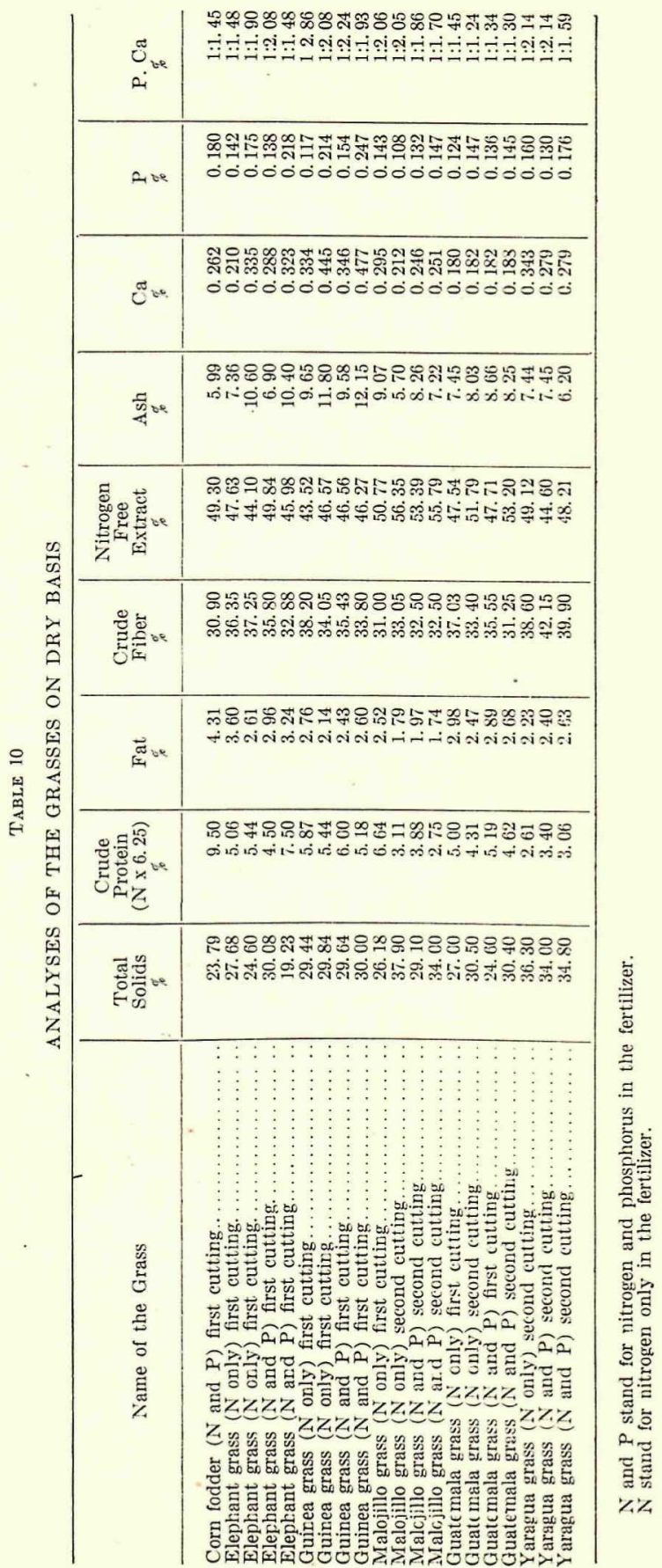


THE JOURNAL OF AGRICULTURE OF THE UNIVERSITY OF P. R.

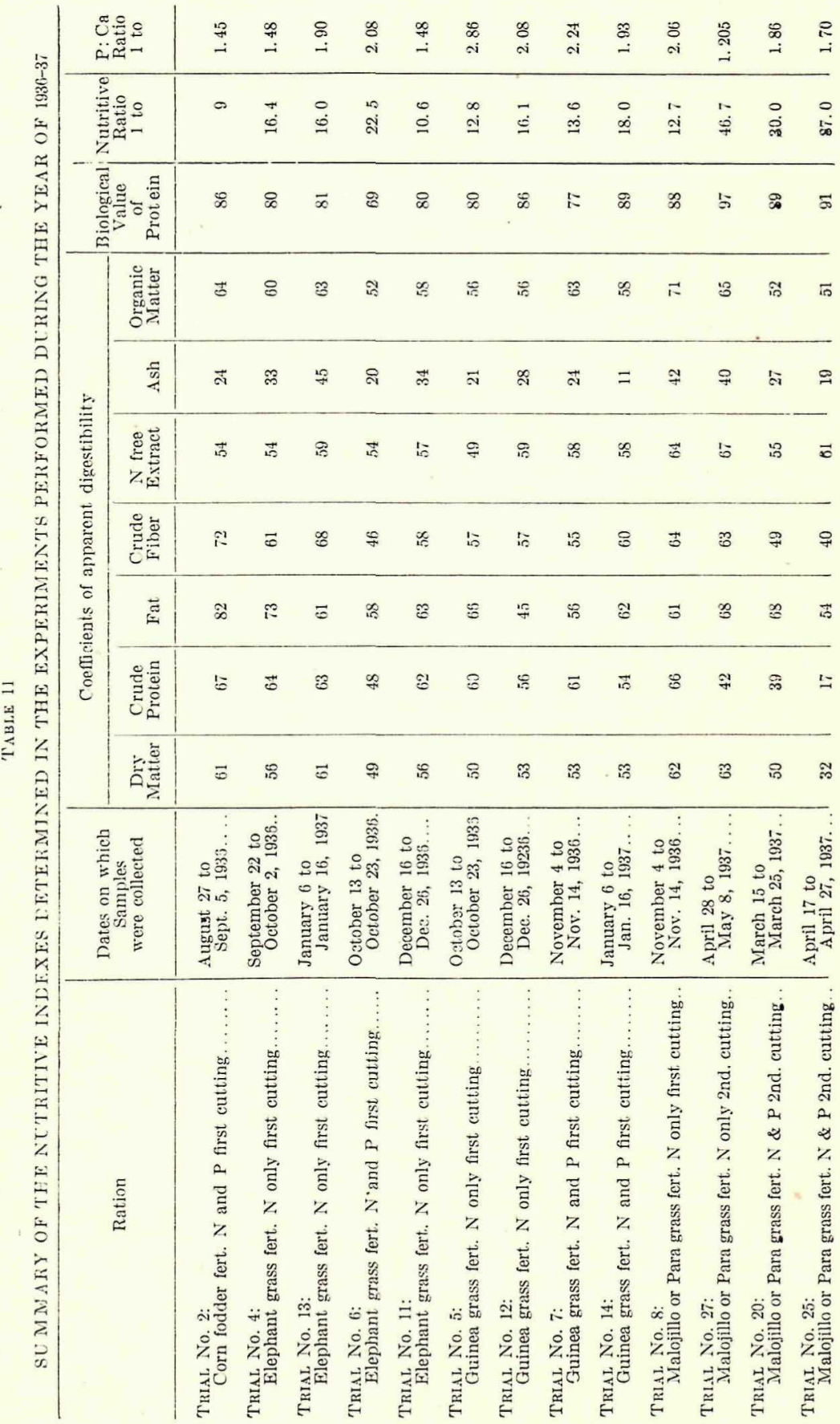




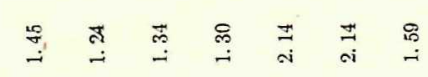

लै

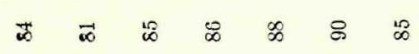

두 \&

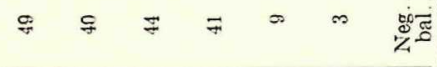

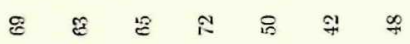

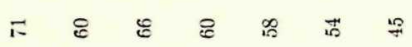

只:

\& เ

\& ๕ ะ ำ ㅇำ

๘ 尔

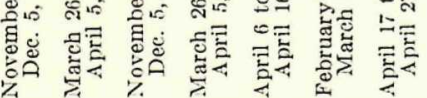

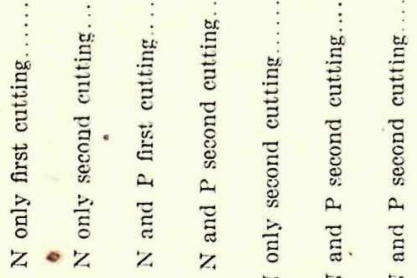

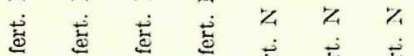
४

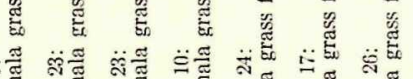
o胥

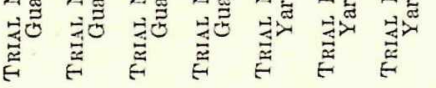

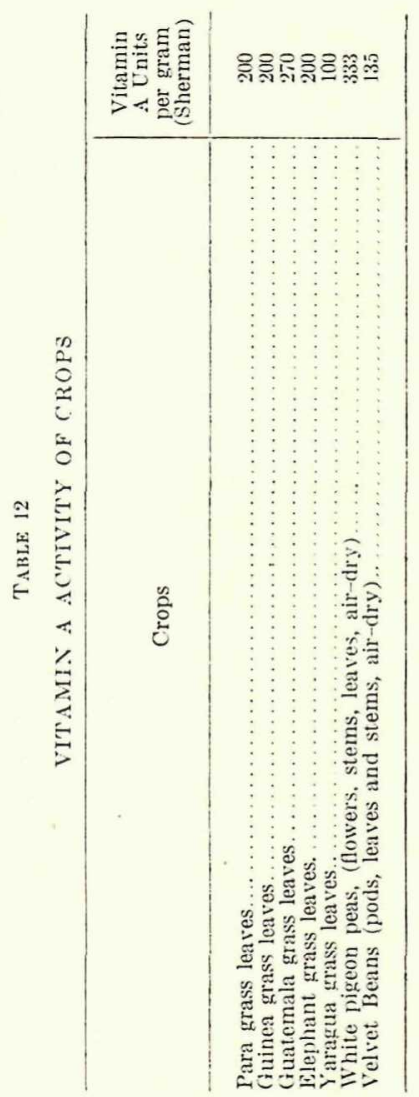

